\title{
Web-Based Classroom Loan Information System (Case Study Student Organizations at Muhammadiyah University of Sidoarjo)
}

\section{Sistem Informasi Peminjaman Ruang Kelas Berbasis Web (Studi Kasus Organisasi Mahasiswa Di Universitas Muhammadiyah Sidoarjo)}

\author{
$1^{\text {st }}$ Alfian Maulana Fajar ${ }^{1}, 2^{\text {nd }}$ Ika Ratna Indra Astutik ${ }^{2}$ \\ \{alfian9107@gmail.com¹,ikaratna@umsida.ac.id ${ }^{2}$ \}
}

Universitas Muhammadiyah Sidoarjo, Indonesia ${ }^{1}$, Universitas Muhammadiyah Sidoarjo, Indonesia ${ }^{2}$

\begin{abstract}
This research was aimed to create a website based information system that can be used for summarize the flow and facilitate borrowing space in the University of Muhammadiyah Sidoarjo by student organizations. The research method used by researchers is the waterfall method, but the data collection technique uses several ways, namely observation, interviews, and also literature study. Researchers made observations in student organizations to obtain data, in addition to met with the Directorate of Asset and Environmental Management to obtain data. The result of this research is that student organizations can borrow space online, and make it easier to recap data and also minimize duplicate data in the system. With more efficient procedures, the borrowing process becomes easier and more practical
\end{abstract}

Keywords - student organizations; borrowing space; website; information system

\begin{abstract}
Abstrak. Penelitian ini bertujuan untuk menciptakan sebuah sistem informasi berbasis laman yang dapat digunakan untuk meringkas alur dan memudahkan peminjaman ruangan yang ada di lingkungan Universitas Muhammadiyah Sidoarjo oleh organisasi mahasiswa. Metode penelitian yang digunakan oleh peneliti adalah metode waterfall, namun teknik pengumpulan datanya menggunakan beberapa cara yaitu observasi, wawancara, dan juga studi pustaka. Peneliti melakukan observasi pada organisasi mahasiswa untuk mendapatkan data, selain itu juga bertemu dengan Direktorat Pengelolaan Aset dan Lingkungan untuk mendapatkan data. Hasil dari penelitian ini adalah organisasi mahasiswa dapat meminjam ruangan secara daring, dan memudahkan dalam merekap data dan juga meminimalisir adanya data ganda pada sistem. Dengan prosedur yang semakin efisien, maka proses peminjaman menjadi semakin mudah dan praktis
\end{abstract}

Kata Kunci - organisasi mahasiswa; peminjaman tempat; laman; sistem informasi

\section{Pendahuluan}

Organisasi mahasiswa adalah suatu perkumpulan di dalam lingkup universitas yang mempunyai visi dan misi serta anggaran dasar anggaran rumah tangga sebagai dasar pendirian suatu organisasi. Organisasi mahasiswa memiliki kedudukan resmi di lingkup perguruan tinggi, bentuknya dapat berada di tingkat universitas, fakultas, serta program studi, ada juga yang berdasarkan bakat dan minat yang dinamakan Unit Kegiatan Mahasiswa atau disingkat UKM. [1] Dalam organisasi mahasiswa, mahasiswa dapat berproses dengan baik melalui pemikiran ataupun tindakan, melatih tanggung jawab dan juga membuat suatu keputusan yang mempunyai landasan berpikir. Mahasiswa yang berorganisasi dan dapat membagi waktunya dengan baik kemungkinan prestasinya meningkat. Melalui gagasan, ide, ataupun tindakan tersebut dapat menghasilkan sesuatu yang berguna untuk masyarakat luas. [2]

Dalam menyalurkan kreatifitas, gagasan serta untuk mengembangkan organisasi tentu dibutuhkan sarana dan prasarana yang baik. Dengan adanya sarana dan prasarana yang baik dan memadai, maka segala kebutuhan organisasi dapat tersalurkan. Namun seringkali dalam pelaksanaannya terhambat oleh beberapa proses dan prosedur, salah satunya adalah ketika akan melakukan peminjaman ruang di lingkungan universitas. Sistem peminjaman yang masih konvensional, yakni organisasi diharuskan menghadap kemahasiswaan dan menunggu proses selama beberapa waktu untuk menunggu proses validasi.

Di era modern ini diperlukan sebuah sistem informasi yang berada di dalam lingkup suatu organisasi yang dapat menyatukan pengolahan dan mendukung fungsi organisasi [3] dimana terdapat informasi untuk semua orang kapan saja diperlukan. Sistem informasi juga dapat melakukan beberapa hal seperti mengolah, mengubah, mengambil dan menyimpan informasi yang diterima. [4] Sistem informasi tersebut berbasis website yang dapat diakses melalui berbagai perangkat dan dapat mempunyai kemampuan memberi rasa aman pada pengguna saat melakukan interaksi, dan mampu memudahkan komunikasi. [5]

Dari permasalahan tersebut maka dibutuhkan sebuah sistem informasi yang terdiri dari beberapa fungsi yaitu pengunduhan form peminjaman, pengajuan peminjaman, serta pemberian surat disposisi, dan informasi lainnya. Dengan adanya sistem informasi berbasis website tersebut maka akan mempermudah organisasi mahasiswa dalam 
mengakses dengan berbagai perangkat dan juga tidak terbatas tempat dan waktu. Juga dapat meminimalisir miskomunikasi ketika akan menggunakan ruangan yang telah dipesan. Selain itu juga website tersebut juga berfungsi untuk merekap kegiatan yang telah dilakukan di lingkungan universitas.

\section{METODE}

\section{A. Objek Penelitian}

Tempat dilaksanakannya penelitian ini adalah di Universitas Muhammadiyah Sidoarjo yang berlokasi di Jl. Mojopahit no. 666B, Sidoarjo. Penelitian ini dilaksanakan mulai dari bulan Oktober 2020. Objek penelitian ini adalah seluruh organisasi mahasiswa yang berada di dalam lingkup Universitas Muhammadiyah Sidoarjo

\section{B. Analisa Sistem}

Pada Sistem sebelumya, kegiatan peminjaman ruang masih bersifat konvensional, yaitu ormawa harus menghadap ke kemahasiswaan untuk menyerahkan surat peminjaman. Kemudian pihak kemahasiswaan berkoordinasi dengan membuat e-surat yang ditujukan ke pihak DPAL untuk mengecek apakah ruangan tersebut tersedia atau tidak. Validasi akan dilakukan oleh DPAL jika ruangan tersebut tersedia dan dapat digunakan. Lalu ormawa diinformasikan mengenai pengambilan surat disposisi melalui pesan pribadi. Oleh karena itu dengan adanya sistem informasi berbasis website maka akan mempermudah peminjaman oleh ormawa dan juga meminimalisir miskomunikasi antara ketiga pihak yang berhubungan.

Dalam penelitian ini peneliti menggunakan beberapa metode yaitu observasi, mengamati prosedur peminjaman ruang dengan cara bergabung dengan ormawa sehingga dapat mengetahui bagaimana alur dan proses peminjaman ruangan. Kemudian melakukan wawancara dengan pihak kemahasiswaan guna mengetahui secara langsung sistem maupun alur peminjaman yang sedang berjalan, selain itu juga peneliti melakukan wawancara dengan pihak Direktorat Pengelolaan Aset dan Lingkungan untuk mendapatkan data terkait fasilitas ruang dan segala hal yang berkaitan dengan fasilitas di universitas. Yang terakhir yaitu mengumpulkan data-data melalui studi penelitian terdahulu yang terdapat di buku, literatur, laporan, dan lain lain.

\section{Diagram Alur Aplikasi}

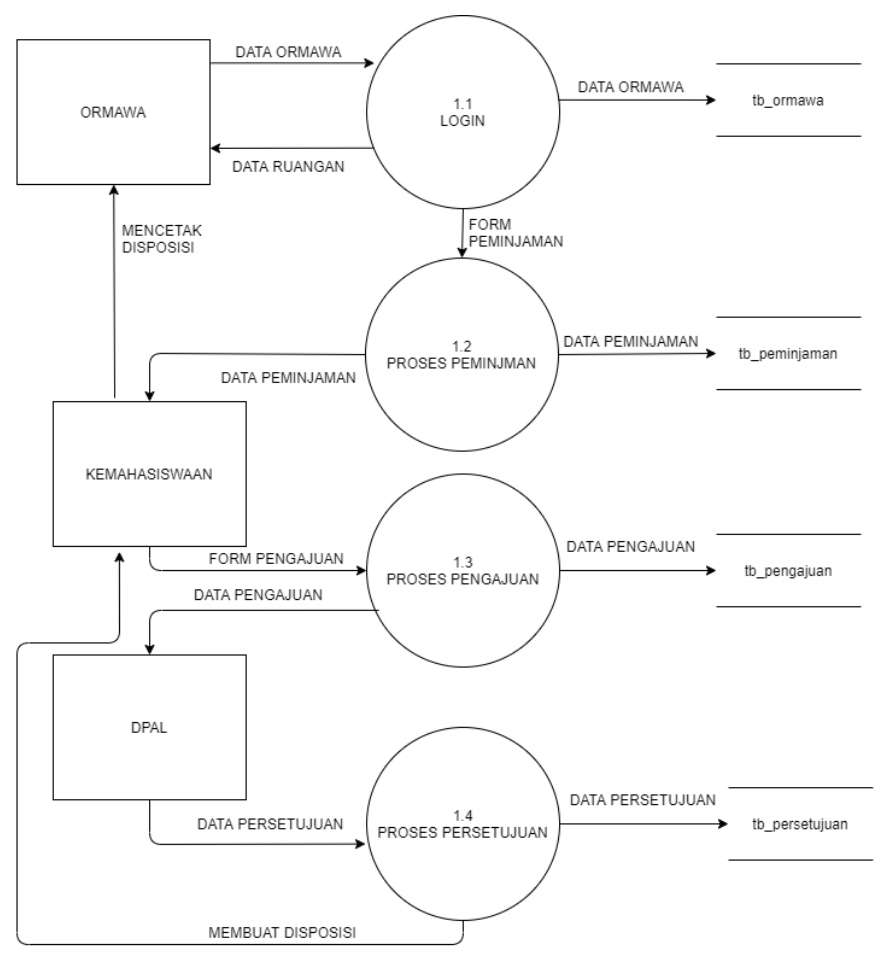

Gambar 1. Data Flow Diagram

DFD (Data Flow Diagram) Merupakan suatu diagram yang menggunakan notasi tertentu untuk menggambarkan arus data dari suatu sistem yang gunanya untuk mempermudah pengguna memahami sistem secara logika, terstruktur dan juga ringkas. [6] Di dalam data flow diagram diatas dapat diartika bahwa Langkah pertama adalah pihak orawa login terlebih dahulu, kemudian setelah itu ormawa dapat melakukan proses peminjaman dengan mengisi form peminjaman. Setelah itu data peminjaman tersebut akan diperiksa oleh pihak kemahasiswaan, jika data yang dimasukkan telah sesuai maka pihak kemahasiswaan akan mengajukan e-surat dengan mengisi form pengajuan ruangan. Setelah itu pihak DPAL akan mengecek ketersediaan dan beberapa hal lain, kemudian menginputkan surat disposisi yang ditujukan pada pihak kemahasiswaan. Setelah itu pihak kemahasiswaan akan mengirimkan disposisi tersebut dan ormawa dapat mengunduh atau mencetak surat disposisi yang telah tersedia yang digunakan untuk peminjaman ruangan. 


\section{Perancangan Antar Muka Website Sistem informasi Peminjaman Ruangan}

Rancangan antar muka merupakan salah satu hal penting dalam membangun website, karena rancangan tersebut adalah gambaran atau hasil kasar dari website yang akan dibangun. Website tersebut dibangun dengan beberapa Bahasa pemrograman yaitu HTML, yang merupakan salah satu Bahasa dasar dalam web scripting yang memungkinkan untuk menampilkan berbagai informasi dalam betuk teks, grafik, serta multimedia. [7] Kemudian untuk tampilannya menggunakan CSS, yang dapat menampilkan halaman yang tampak sama meskipun resolusi layarnya berbeda-beda sehingga akan dapat lebih memudahkan pengguna karena lebih fleksibel. [8] Untuk server side scripting, peneliti menggunakan PHP karena dapat dijalankan pada semua sistem operasi yang umum seperti UNIX, Windows, dan MacOS. [9] Sedangkan untuk sistem manajemen basis data yang digunakan yaitu basis data MySQL, sistem tersebut sederhana dan mudah digunakan. [10] Dalam hal ini peneliti merancang desain yang simpel, namun tetap informatif.

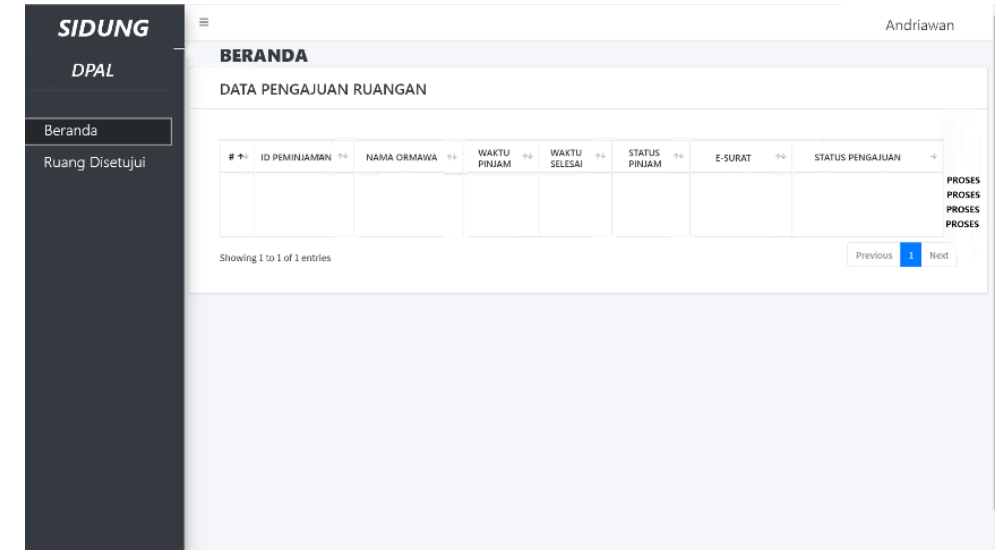

Gambar 2. Rancangan antarmuka halaman utama DPAL

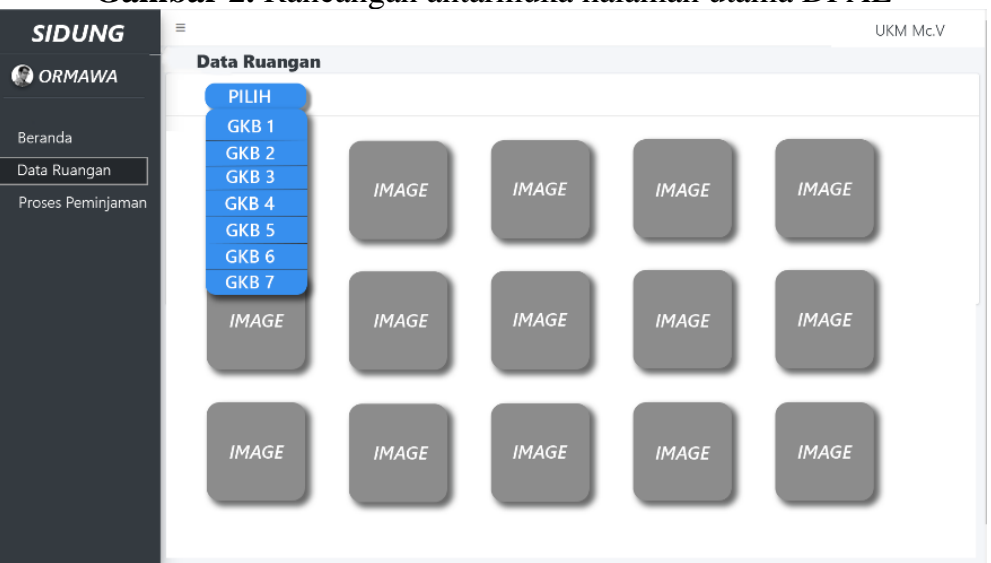

Gambar 3. Rancangan antarmuka data ruangan untuk ormawa

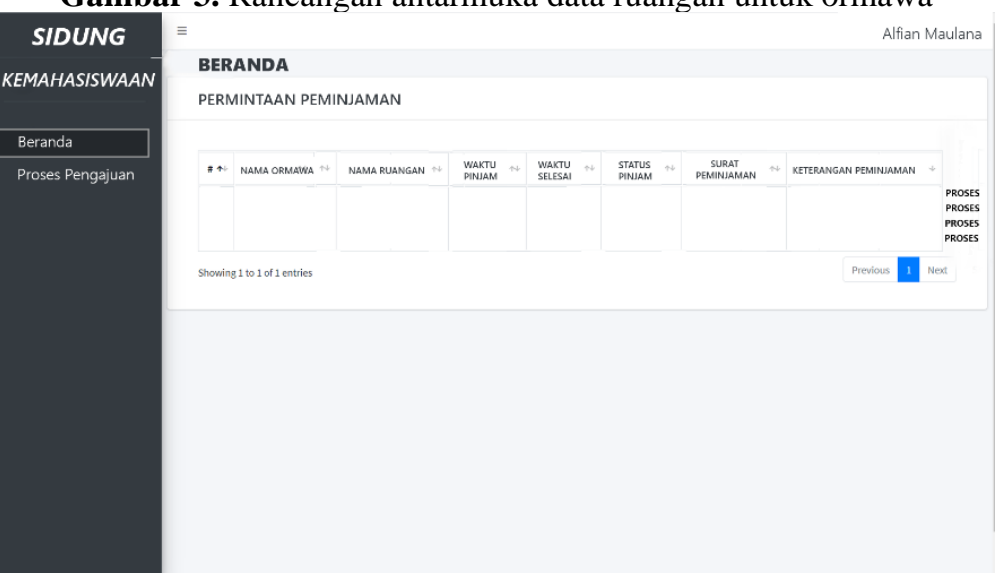

Gambar 4. Rancangan antarmuka halaman utama untuk kemahasiswaan 


\section{HaSil Dan PEMbahaSAN}

\section{A. Implementasi Antarmuka Halaman Ormawa}

Pada implementasinya, halaman utama ormawa berisi data ruangan yang berada di masing-masing gedung, sehingga ormawa akan mempunyai gambaran mengenai ruangan mana yang akan dipinjam
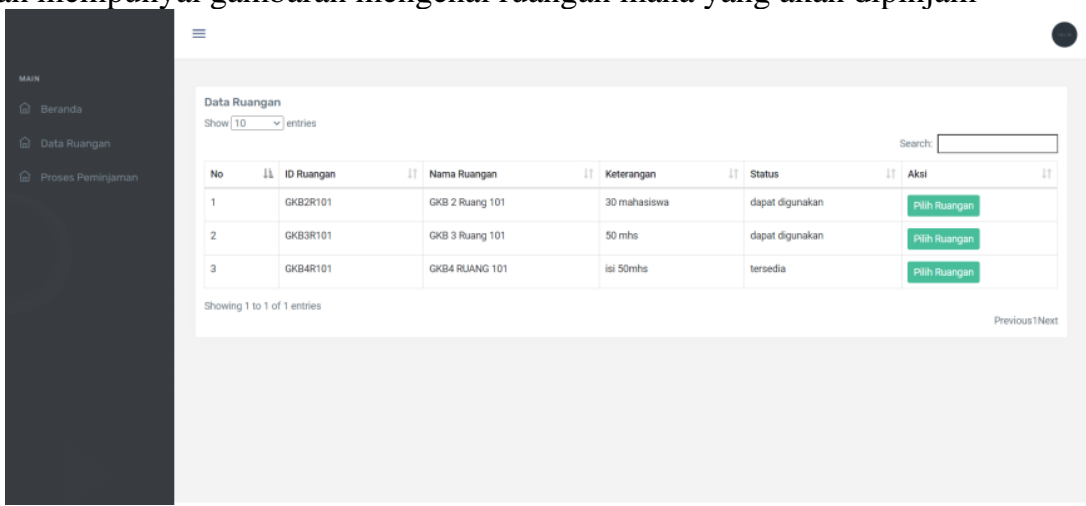

Gambar 5. Tampilan halaman data ruangan

Seteleha memilih ruangan yang tersedia selanjutnya adalah mengisi form peminjaman yang berisikan data-data seperti Tanggal, ruangan yang digunakan, lama peminjaman, dan lain lain.

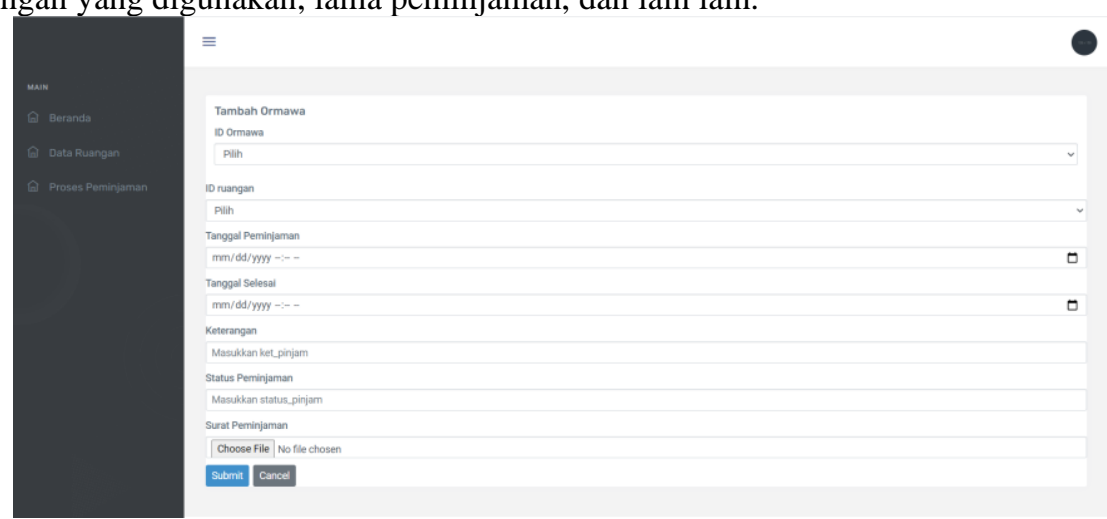

Gambar 6. Tampilan halaman form peminjaman 


\section{B. Implementasi Antarmuka Halaman Kemahasiswaan}
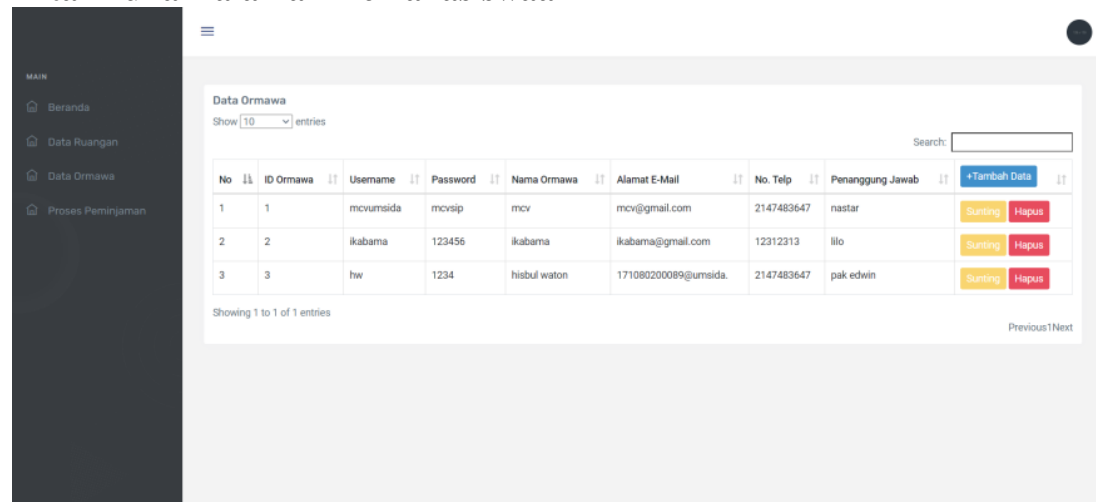

Gambar 7. Tampilan halaman data ormawa

Pihak Kemahasiswaan mempunyai akses untuk melihat, menambahkan, menyunting ataupun menghapus data ormawa. Di halaman ini terdapat beberapa data ormawa seperti username, password, dan data ormawa yang lainnya.
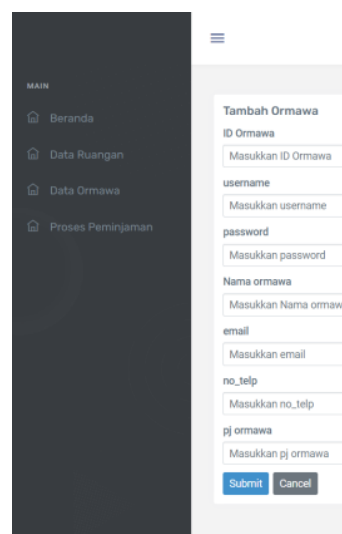

Gambar 8. Tampilan form menambahkan ormawa

Jika akan menambahkan data ormawa baru, maka pihak kemahasiswaan akan mengisi beberapa form yang berisi data-data profil ormawa.

\section{Implementasi Antarmuka Halaman DPAL}
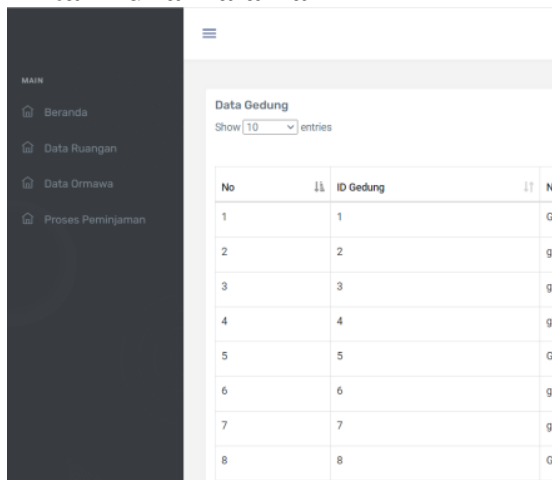

Gambar 9. Tampilan halaman data gedung

Pihak DPAL dapat melihat, menyunting, menambahkan dan menghapus data-data terkait sarana prasarana di lingkungan universitas seperti data gedung, data ruangan, fasilitas ruangan, dan lain-lain. 


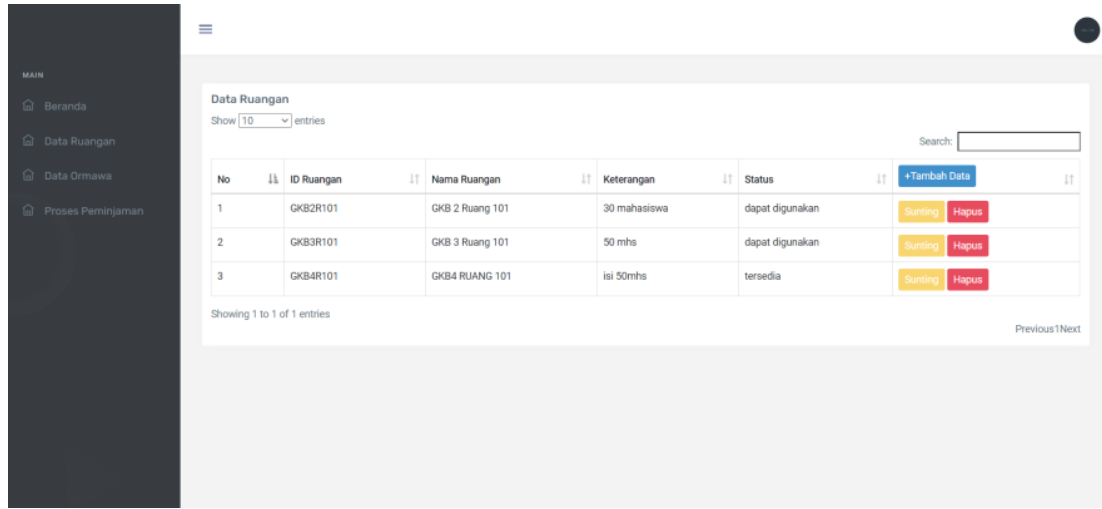

Gambar 10. Tampilan halaman data ruangan

Halaman data ruangan berisi informasi tentang ID ruangan, nama ruangan, serta fasilitas-fasilitas yang terdapat pada ruangan tersebut.

\section{KESIMPULAN}

Berdasarkan hasil yang sudah dilakukan, kesimpulan yang dapat diambil adalah website ini membantu memudahkan peminjaman ruang oleh ormawa. Meskipun terdapat banyak kekurangan pada website ini, namun ini adalah Langkah awal yang baik untuk meringkas alur peminjaman serta mengikuti perkembangan zaman yang semuanya sudah serba digital.

\section{UCAPAN TERIMA KASIH}

Penulis sangat bersyukur kepada Allah SWT karena dapat menyelesaikan jurnal ini dengan lancar dan tanpa kendala yang berarti. Penulis juga berterima kasih kepada semua pihak yang membantu penulisan jurnal ini, kepada pihak ormawa yang bersedia menjadi objek penelitian, pihak kemahasiswaan yang membantu memberikan data-data terkait alur peminjaman dan data-data ormawa lainnya, dan juga pihak DPAL yang telah bersedia memberikan datadata terkait ruangan dan fasilitas yang tersedia di lingkungan Universitas Muhammadiyah Sidoarjo.

\section{REFERENSI}

[1] F. Hendra, "Peran Organisasi Mahasiswa Dalam Meningkatkan Mutu Pembelajaran Keterampilan Berbahasa Arab," Arab. J. Pendidik. Bhs. Arab dan Kebahasaaraban, vol. 5, no. 1, pp. 103-120, 2018, doi: 10.15408/a.v5i1.7480.

[2] S. S. Pratiwi, "Pengaruh Keaktifan Mahasiswa Dalam Organisasi Dan Motivasi Belajar Terhadap Prestasi Belajar Mahasiswa Fakultas Ekonomi Universitas Negeri Yogyakarta,” J. Pendidik. dan Ekon., vol. 6, no. 1, pp. 54-64, 2017, [Online]. Available:

http://journal.student.uny.ac.id/ojs/index.php/ekonomi/article/view/6074.

[3] Sutabri, Konsep Sistem Informasi. CV. Andi Offset, 2012.

[4] E. . Anggraeni and R. Irviani, Pengantar Sistem Informasi. CV. Andi Offset, 2017.

[5] W. Sastika, "Analisis Pengaruh Kualitas Website (WebQual 4.0) Terhadap Keputusan Pembelian pada Website e-commerce Traveloka," Sentika, vol. 2016, no. Sentika, pp. 18-19, 2016.

[6] R. Purnomo and A. Nurdin, "Aplikasi Layanan Delivery Order Berbasis Web Pada Rumah Makan Podoteko," semanTIK, vol. 3, no. 2 ISSN : 2502-8928, pp. 23-30, 2017.

[7] sovia dan Febio, "MEMBANGUN APLIKASI E-LIBRARY MENGGUNAKAN HTML, PHP SCRIPT, DAN MYSQL DATABASE Rini Sovia dan Jimmy Febio,” Processor, vol. 6, no. 2, pp. 38-54, 2011.

[8] B. Kurniawan, Desain Web Praktis dengan CSS. Jakarta: PT. Elex Media Komputindo, 2008.

[9] A. F. Harismawan, A. P. Kharisma, and T. Afirianto, "Analisis Perbandingan Performa Web Service Menggunakan Bahasa Pemrograman Python, PHP, dan Perl pada Client Berbasis Android,” J. Pengemb. Teknol. Inf. dan Ilmu Komput. Univ. Brawijaya, vol. 2, no. January, pp. 237-245, 2018, [Online]. Available: http://j-ptiik.ub.ac.id/index.php/j-ptiik/article/view/781.

[10] I. Warman and R. Ramdaniansyah, "ANALISIS PERBANDINGAN KINERJA QUERY DATABASE MANAGEMENT SYSTEM (DBMS) ANTARA MySQL 5.7.16 DAN MARIADB 10.1,” J. Teknoif, vol. 6, no. 1, pp. 32-41, 2018, doi: 10.21063/jtif.2018.v6.1.32-41. 